\section{International Scientific Journal Theoretical \& Applied Science}

\author{
p-ISSN: 2308-4944 (print) e-ISSN: 2409-0085 (online) \\ Year: $2015 \quad$ Issue: $04 \quad$ Volume: 24
}

Published: $30.04 .2015 \quad$ http://T-Science.org
Zilola Sobirzhonovna Abdullaeva

Senior lecturer, 1st academic Lyceum named Sirojiddinov, Tashkent, Uzbekistan gulom82@yahoo.com

SECTION 29. Literature. Folklore. Translation Studies.

\title{
ART DESCRIPTION AND NATURE OF THE IMAGES IN THE STORIES OF CHULPAN
}

Abstract: The deals with the description art and nature images in the stories of Uzbek writer Chulpan and analyzed his stories by literary scientifically.

Key words: stories, image, ideology, mythical stories.

Language: Russian

Citation: Abdullaeva ZS (2015) ART DESCRIPTION AND NATURE OF THE IMAGES IN THE STORIES OF CHULPAN. ISJ Theoretical \& Applied Science 04 (24): 36-39.

Soi: http://s-o-i.org/1.1/TAS*04(24)6 Doi: crossef http://dx.doi.org/10.15863/TAS.2015.04.24.6

\section{ХУДОЖЕСТВЕННОЕ ОПИСАНИЕ И ПРИРОДА ОБРАЗОВ В РАССКАЗАХ ЧУЛПАНА}

Аннотация: В статье раскрыта художественное описание и природа образов в рассказах узбекского писатель Чулпана и проанализированы его рассказы.

Ключевые слова: рассказы, образ, идеология, мифических сюжетов.

Абдулхамид Сулейман угли Чулпан внес своеобразную лепту в развитие не только узбекской поэзии XX века, но и в формирование и развитие прозы. Его имя упоминают наряду с интеллигенцией того времени, преданными Родине людьми, проводившими реформы в культуре, духовности и просветительстве, как Абдурауф Фитрат, Абдулла Авлони, Махмудходжа Бехбуди, Мунавваркары Абдурашидов, Элбек и Абдулла Кадыри. Чулпан - яркая звезда нашей прозы, его искусство многогранно и прекрасно.

Об этом литературовед, научный деятель Умарали Норматов говорит следующее: “Новая узбекская литература, которая начала формироваться в начале века, избегая традиционных, мифических сюжетов, переходила на создание художественных произведений, основанных на реальных сюжетах. Однако очень часто не все шло гладко. Преображение реальной жизни в искусство, реальных людей в художественные образы, героев проходило очень сложно. Кадыри и Чулпану первыми это удалось, их проза могла состязаться с лучшими поэтическими перлами Востока. Герои Кадыри и Чулпана, взятые из реальной жизни, заняли свое место в сердцах народа наряду с героями дастанов, баллад [4, ст. 64]. Стоит отметить, что творчество Чулпана, как и Фитрата и Кадыри стало важным начальным этапом, образцовой школой в развитии национальной прозы, в частности национального рассказа.

Известно, что в 20-е годы ХХ столетия в нашей стране царили тяжелое политическое положение, экономическая нищета и социальная путаница. Происходящие события не могли оставить равнодушными ни одного джадида. Чулпан также был одним из таких представителей преданных джадидов. Однако он был среди тех, кого не признали, безвинно казнили, он был среди преданных сынов отечества. Это стало большой потерей для нашей литературы, потерей великого гения, способного творить ради духовного становления народа.

Изучение, широкое исследование творчества (поэзии, прозы и художественных произведений) Чулпана началось через несколько лет после его оправдания, а точнее в 1987 году. Более широкое изучение приходится на первые годы независимости. Огромную роль в реабилитации имени поэта, возвращении народу его бесценного 
творчества сыграл известный ученыйлитературовед Озод Шарафиддинов.

Ученый внес большой вклад в исследование жизни и творчества, в частности лирики и прозы поэта и писателя. Шарафидинов издал много научных и публицистических статей, посвященных творчеству Чулпана, что сыграло важную роль в возрождении любви народа к творчеству писателя. В частности, важное значение имели последовательно опубликованные статьи ученого “О творческом пути Чулпана" (1988 г), “В душе останется его след” (1990), “Малые прозаические произведения Чулпана" (1990).

Под научным руководством ученого было написано много научно-исследовательских работ и научных статей, посвященных поэтике и художественному мастерству Чулпана. Среди таких работ - статьи Н.Владимировой "Красивые сюжеты национальной жизни”, "Клеопатра в толковании Чулпана", “Чулпан - рассказчик”, работы Салохиддина Мамажанова "Прозаическое творчество Чулпана", статьи Эрика Каримова “Далекая яркая звезда" и кандидатская диссертация Дилмурода Куръонова "Прозаическая поэтика Чулпана", а также монографии Наима Каримова “Чулпан”. Эти научные труды интересны с точки зрения изучения поэтических факторов художественного своеобразия рассказов Чулпана.

Известно, что прозаическое наследие Чулпана составляет помимо романа “День и ночь”, ряд малых рассказов. В их числе “Тюльпан на снегу”, “Девушка-пекарь”, “Светлые ночи”, “Доктор Мухамадиёр”, “Жертва зла”, “Завтрак”, “Гавхарой”, "Клеопатра”, “Тараккий” и "Подарок белого царя”. Тематика опубликованных в свое время в периодических изданиях рассказов разнообразная.

Как отмечают наши литературоведы, формирование жанра национального рассказа, несомненно, определяется правдоподобностью созданных национальных героев. То есть, каждый рассказ Чулпана привлекает колоритностью красок национальных героев, богатством ярких и неповторимых картин жизни народа. В рассказах “Девушка-пекарь”, “Светлые ночи” посредством эволюции сюжета можно наблюдать за совершенствованием героев на протяжении произведения. Теперь по таким рассказам, как “Тюльпан на снегу”, “Завтрак” посредством картины бытовой жизни будут изучаться психология личности, социального поведения" [1, ст. 44].

Когда мы наблюдаем за художественными особенностями рассказов Чулпана, бросается в глаза то, что здесь уместно каждое слово, они неповторимы. Особо стоит отметить, что писатель посредством передачи пейзажей пытается передать свои настроения, намекая на художественные цели. Слова выполняют не только функцию сухой передачи смысла. Художественное мастерство Чулпана выражается в создании образов и эффективном использовании средств художественного выражения.

Мы в рассказах писателя будем указывать не на его художественное мастерство, но на особенности художественного изображения. Так как, когда речь идет о жанре рассказа, в качестве важного фактора оценивается его описание. В рассказе на первый план выставляется лишь эпизод взятого за основу материала. Хотя эти произведения могли быть написаны в аспекте не одного персонажа, а нескольких героев. Однако писателя не интересуют другие эпизоды и характеры.

Основная особенность, определенная в качестве материала жанра рассказа способ изображения писателя [1, ст. 85$]$.

Действительно, в каждом произведении автор при помощи изображения передает пейзажи эпохи, в художественной манере воссоздает духовно-эмоциональный мир и переживания героя.

Одним из зрелых, идейно богатых, полных изображения и пейзажей рассказов является «Девушка-пекарь». Этот рассказ можно охарактеризовать, прежде всего, как один из уникальных, способных померяться в оригинальности даже с новеллами, передающими социальную жизнь зарубежных стран.

Главный герой рассказа - девушка-пекарь, зарабатывающая на жизнь продажей хлеба, таким образом, обеспечивая себя и свою больную мать. На сюжетной линии появляется противопоставляемый ей антигерой - мясник Улмасбай. На самом деле сюжет рассказа строится на отношениях этих двух героев. Девушка-пекарь обманута «неправедным» Улмасбаем, сказавшим «пойдем ко мне домой, у меня дома есть, я возьму весь твой хлеб». Весь мир девушки был перевернут с ног на голову, Чулпан мастерски смог изобразить всю гамму чувств, которую пережила опороченная девушка. Беспомощная, слабая девушка бросила врагу «неправедный, смог бросить пиалу» [7].

Девушка, «давным-давно похоронившая в своем черном мире свою мать», отдала Богу больную мать, общество узнало об их «играх» с Улмасбаем - все это приносило ей огромные страдания, дальнейшая ее жизнь раскрывается через повествование и описание автора. Девушке, «побывавшей за двумя мужьями», писатель дает следующее лаконичное и точное описание. «Теперь остались лишь старые, порванные лохмотья, истерзанное сердце, уставшее тело, потерянная душа» [7]. 
Трагедия, вызванная грязными и грубыми, духовно бедными людишками этого несправедливого общества, не признававшего моральных устоев, попрание ценности Человека, ее прав и интересов - все это ярко выражено в образе обесчещенной Девушки-пекаря.

Действительно, Чулпан описывает события в рассказе так правдоподобно и в точных красках, что вам не жаль времени на слежение за сюжетом. В данном рассказе автор применяет в прозаическом жанре свойственное лирике метафорическое сравнение. А это считается важным средством описания противопоставляемых отношений, чувств двух героев.

«... Море, будучи таким великим, сдается перед берегами. Когда оно злится, оно бросает свои малые волны о подобный металлу берег. И хоть бы это хоть как-то подействовало на берег. Бедные волны, разбившись, они снова возвращаются в море. Оно их приласкает, ободрит и снова бросит о каменный берег. И снова разбитые волны, снова возвращение домой. Нескончаемая битва!» [7].

Особого восхищения заслуживает мастерство художественного описания пейзажа талантливого писателя.

Гордость девушки, женская красота, величие женской души, все это автор передает в гениальных аллегориях. Необдуманный поступок «неправедного» парня по отношению к невинной девушке - это грех, в конце рассказа он еще ответит за это. Эта невинная девушка спустя время станет одной из первых, кто скинул паранджу, и дойдет до председателя женского комитета.

Не зря автор поднимает тему женского права, как в лирических произведения, так и в прозе. Чулпан показывает в трагедии героев всю несправедливость системы, общества, правящей в то время идеологии. Девушка - Море, а парень не сумевший обуздать собственную страсть неумолимый Берег. Через душевные переживания девушки Чулпан передает свои думы о народе.

«Ах! Могут ли попавшие в заключение свободно избавиться от кабалы? Есть ли жалость в пасти у волка? Может ли лев отпустить на волю пойманную добычу? А дракон, если он существует, разве добился он своей славы добрыми делами? Глубокие бездны, высокие скалы, ужасные намеки... есть ли задача человека поднимать свое дитя? Поцелует ли нож? Погладит ли твое чело кинжал? Использует ли скорпион свое жало для шитья? Нет...» [7].

Не зря писатель поднимает волнующие душу девушки вопросы. Трагедия девушки - это не только ее трагедия, но и всей нации, страны.
Здесь стоит привести слова известного чулпановеда Озода Шарафиддинова:

«Чулпан - был поэтом, обладающим чрезвычайным талантом. Его поэтическая душа тонко чувствовала мир, отзывалась на все жизненные перипетии. Его острый взгляд проникает в затаенные уголки души человека. Глубокий ум постигает всю суть происходящих событий. Мастерство Чулпана было настолько высоко, что легким движением пера он мог вести войско слов в любом направлении» [8].

Действительно, во времена деспотического режима мечта о Свободе и Независимости была желанием в основном просвещенных людей, смыслом их жизни. Описание в этом рассказе Чулпана вылилось в скрытое выражение этих потаенных благородных желаний народа.

С первого взгляда кажется, что в рассказе «Девушка-пекарь» описание героев, личная судьба, изменения в душевном настроении, колебания, конфликты и другие психологические процессы здесь на первом месте, однако стоит подчеркнуть, что, в первую очередь, перед автором стоит создание эстетического идеала. Да, мы наблюдаем, как под влиянием общества происходят изменения в природе героя, осознание своей чести, борьбу против тех, кто хочет надругаться над ней, видим силу воли. Несмотря на то, что автор создает образ Девушки-пекаря, осознавшей преимущество новой жизни, смысл нового существования, описания душевных переживаний героини служат также передачи ее взглядов на Свободу и Раскрепощение.

Исходя из этого, хотим привести некоторые выводы, полученные в ходе анализа данного рассказа.

Изменение сознания людей, усиление чувства собственного достоинства привело к острой необходимости реалистичной передачи сложности человеческих отношений, социальных отношений между личностью, действительностью, обществом.

Например, в рассказе «Девушка-пекарь» имеются свойственные реалистическим произведениям состояние, характеры, настроение; пейзаж души, описание конкретных признаков, отражающих ее изменения; имеется четкий облик безнравственности, оскорбившей человечность, человеческие чувства. Писатель не объясняет смысл произошедшего. Он воссоздает для нас картину, увиденную им своим тонким и чувствительным взглядом. В частности, девушка мстит мяснику Улмасбою. «Ничто в жизни не исчезает бесследно, каждый получает по заслугам» - этот философский смысл лежит в основе произведения [1, ст. 88].

В данных выводах видно, что смысл рассказа «Девушка-пекарь», художественное 
своеобразие истолковано односторонне. Однако именно этот рассказ писателя проанализирован нами в аспекте художественного описания, отразившего высокое мастерство и потенциал писателя.

К примеру, начало, кульминация и развязка двусторонних отношения между двумя героями в прозаическом описании реализуется посредством системы сравнений.

«Когда снова будет суд...

Море - девушка подобно рабу молвила.

Берег - Улмасбай подобно скале тихо внимал.

Берег опрокинулся.

Скала пала.

Морские волны и валы приняли их в свои объятия, чтобы спасти от берегов, погрузились в чувства оберега.

«Падение Берега, падение скалы - это выражение недолговечности системы и мечта о торжестве справедливости; с одной стороны здесь налицо проявление традиционных в народных сказках сюжетов, когда победа на стороне добра в борьбе добра и зла, и в то же время мастерство Чулпана выражается в том, что он не просто повествует, в этом его гений»

В самом деле, писателя в описании состояния героя изображает его душевные переживания, волнения посредством внешнего описания:

К образу Девушки-пекаря делает следующие штрихи: «Она почувствовала, как всего два слова
«Девушка» и «душенька моя» словно два копья по очереди вонзились в ее тело».

Чулпан уже только этими словами передает всю масштабность душевных переживаний героини. Автор не характеризует тон мясника Улмасбая, когда тот обратился «душенька моя». Однако по тому, как эти слова «подобно двум копьям» вонзились в тело героини, можно понять сколько иронии и издевки в этой фразе.

В рассказе очень много примеров, когда писатель, описывая состояние и душевное настроение героев широко использовал средства художественной выразительности, в частности, много сравнений.

«Она задрожала, ее губы подобно листьям, летящим навстречу ветру, начали судорожно трепетать. Грудь сжималась, дыхание становилось тяжелым, появилась одышка».

Она задрожала, ее губы подобно листьям, летящим навстречу ветру - едва ли заметное природное явление под пером мастера стало одним из самых прекрасных сравнений в произведении. Дрожь девушки появилась вовсе не из-за страха, это видно из данной аллегории. Ненависть к произошедшему, нескончаемая боль нашла свое выражение в данном сравнении.

Неповторимое описание, ставшее выражением высокого мастерства писателя в рассказе «Девушка-пекарь» отличается своей обаятельностью. Данное произведение, появившееся на заре XX века, можно охарактеризовать, как один из красивейших образцов узбекского реалистического рассказа.

\section{References:}

1. (1992) Adabiy tur va zhanrlar. 3 zhildlik. Toshkent, 1992.

2. Belokurova SP (2007) Slovar' literaturovedcheskikh terminov, - SPb.: Paritet, 2007.

3. (1987) Literaturniy entsiklopedicheskiy slovar. - Moscow, 1987.

4. Normatov U (2002) Mutelikka қarshi isen. Til va adabiet ta"limi. 2002. № 4 .

5. Fayzullaeva MN (1991) «A. P. Chekhov i Chulpan». Sbornik nauchnykh staten professorsko-prepodavatel'skogo sostava Tashkentskogo oblastnogo gosudarstvennogo pedagogicheskogo instituta. Seriya literatura i yazyk, g. Angren, 1991.
6. Fayzullaeva MN (1991) «Gore» A. P. Chekhova $\mathrm{V}$ perevode Chulnana. Sbornik nauchnykh statey professorskoprepodavatel'skogo sostava Tashkentskogo oblastnogo gosudarstvennogo pedagogicheskogo instituta. Seriya literatura i yazyk, g. Angren, 1991 g. (Prinyato v pechat').

7. (1994) Chy̆lpon. Asarlar. 3 zhildlik. T.: Adabiet va san"at, 1994. 1-zhild.

8. Sharafiddinov O (1989) Ky̆ngilda қоlғusi uning bir izi. - T., 1989. № 2.

9. Quronov D (2004) Adabiyotshunoslik nazariyasi asoslari .-T.: «Xalq merosi» nashriyoti, 2004.

10. Sultonov I (2002) Adabiyot nazariyasi.-T.: «O`qituvchi», 2002. 